\title{
Pembelajaran Daring di Masa Pandemi Covid-19: Persepsi Mahasiswa Berbasis Gender
}

\author{
Dadang Warta Candra Wira Kusuma ${ }^{1}$, Agus Muliadi ${ }^{2 *}$, Fathurrahman Imran ${ }^{3}$ \\ ${ }^{1}$ Pendidikan Olahraga, FIKKM, Universitas Pendidikan Mandalika, Indonesia \\ ${ }^{2}$ Pendidikan Biologi, FSTT, Universitas Pendidikan Mandalika, Indonesia \\ ${ }^{3}$ Pendidikan Bahasa Inggris, FBMB, Universitas Pendidikan Mandalika, Indonesia \\ *Corresponding Author E-mail: agusmuliadi@undikma.ac.id
}

\begin{abstract}
Abstrak
Tujuan penelitian ini adalah untuk mengetahui persepsi mahasiswa pendidikan olahraga terhadap efektivitas pembelajaran daring pada masa pandemi Covid-19 ditinjau berdasarkan gender. Penelitian ini merupakan penelitian eksploratif dengan subyek penelitian sebanyak 166 mahasiswa pendidikan olahraga Universitas Pendidikan Mandalika. Instrumen yang digunakan berupa angket tertutup dengan skala Likert dan yang telah divalidasi (validasi ahli). Data penelitian dianalisis secara deskriptif dan statistik inferensial dengan uji-t. Hasil studi yaitu (1) persepsi mahasiswa terhadap pembelajaran daring pada pendidikan olahraga ditinjau dari gender yaitu laki-laki memiliki rata-rata skor sebesar 2,23 dengan kategori Cukup Baik dan perempuan sebesar 2,02 dengan kategori Cukup Baik; (2) ada perbedaan yang signifikan persepsi mahasiswa terhadap pembelajaran daring antara mahasiswa berjenis kelamin laki-laki dan perempuan yang dibuktikan dengan nilai signifikansi sebesar 0,023 lebih kecil dari nilai alpha pengujian 0,05 $(<0,05)$. Oleh sebab itu, dapat disimpulkan bahwa pembelajaran daring di pendidikan olahraga pada semester genap tahun akademik 2019/2020 di masa pandemi covid-19 berlangsung kurang efektif.
\end{abstract}

Kata kunci: pembelajaran daring, pandemi covid-19, persepsi mahasiswa, gender

\section{PENDAHULUAN}

Pendidikan merupakan usaha sadar untuk menyiapkan generasi bangsa melalui kegiatan bimbingan, pengajaran, dan latihan demi peranannya dimasa mendatang (Muliadi, Mirawati \& Jannah, 2021). Pembelajaran adalah aktivitas proses belajar yang dilakukan peserta didik yang bertujuan untuk memperoleh pengalaman, meningkatkan kemampuan, meningkatan pengetahuan yang tidak tahu menjadi tahu atau dari tidak mengerti menjadi mengerti (Hilmiatussadiah, 2020). Pendapat lainnya disampaikan oleh Maulah, Nurul \& Ummah (2020) bahwa kegiatan pembelajaran merupakan salah satu komponen utama dalam pendidikan yang pelaksanaanya harus dipastikan dapat terselenggara secara baik dan berkesinambungan. Pada masa pandemi covid19 saat ini, pemerintah harus memberikan kepastian penyelenggaraan kegiatan pembelajaran dapat terus berlangsung melalui penyesuaian metode yang dan tetap mematuhi protokol kesehatan yang berlaku.

Pandemi wabah corona virus disease 2019 yang berlangsung lebih dari setahun dan telah menjangkit penduduk internasional sekitar 215 negara di dunia termasuk Indonesia (Muliadi, Mirawati \& Jannah, 2021; Muliadi, et al, 2021). Wabah ini tidak saja menggerogoti sisi kesehatan masyarakat dunia, namun telah memberikan dampak sistemik pada semua aspek kehidupan termasuk dunia pendidikan. Pemerintah secara resmi telah melarang adanya kegiatan yang mengundang kerumunan, pembatasan sosial (social distancing), menjaga jarak fisik (physical distancing), memakai masker dan selalu cuci tangan (Gultom \& Sitanggang, 2020; Sadikin \& Hamidah, 2020). Oleh karena itu, kegiatan pembelajaran secara langsung pun dihentikan secara nasional.

Pemerintah Indonesia dalam hal ini kementerian pendidikan dan kebudayaan telah mengeluarkan kebijakan tentang penyelenggaraan pembelajaran secara daring (online) melalui terbitnya Surat Edaran Nomor 3 Tahun 2020 tentang pencegahan penyebaran covid-19 pada satuan pendidikan. Program pembelajaran daring (online) diterapkan dari berbagai tingkatan pendidikan di Indonesia tanpa terkecuali termasuk perguruan tinggi. 
Perguruan tinggi dituntut agar dapat menyelenggarakan pembelajaran secara daring atau online (Firman \& Rahayu, 2020).

Perguruan tinggi di Indonesia merepon kebijakan yang ditetapkan pemerintah dan menyelenggarakan pembelajaran daring termasuk Universitas Pendidikan Mandalika. Pembelajaran langsung (tatap muka) ditiadakan dan menggantinya dengan pembelajaran daring (online) dengan berbagai jenis media yang tersedia. Pembelajaran daring (online) pada Pendidikan Olahraga Universitas Pendidikan Mandalika dilaksanakan dengan memanfaatkan teknologi dan media internet secara synchronous atau asynchronous. Muliadi, Mirawati \& Jannah (2021) menjelaskan bahwa pada era 4.0 saat ini akan memudahkan kita melaksanakan pembelajaran online karena pesatnya perkembangan teknologi informasi. Masyarakat sudah cukup lama dimanjakan dengan berbagai media sosial, yang memudahkannya berkomunikasi tanpa mengenal batas daerah. Oleh sebab itu, pembelajaran daring di perguruan tinggi dapat diselenggarakan secara cepat dan langsung menggunakan media sosial yang tersedia, seraya dievaluasi efektivitasnya. Pembelajaran daring secara tidak langsung menguji kemampuan kreativitas, inovasi, profesionalisme, dan keterampilan dosen dalam mengajar dengan pola baru (Maulah, Nurul \& Ummah, 2020; Pangondian, Santosa, \& Nugroho, 2019).

Pembelajaran daring merupakan pembelajaran menggunakan jaringan internet dengan aksesibilitas, konektivitas, fleksibilitas, dan memungkinkan adanya berbagai jenis interaksi pembelajaran (Sadikin \& Hamidah, 2020). Pendapat lainnya disampaikan oleh Kuntarto (2017) bahwa pembelajaran daring adalah pembelajaran yang mampu mempertemukan mahasiswa dan dosen untuk melaksanakan interaksi pembelajaran dengan bantuan internet. Saifudin (2017) menjelaskan bahwa momentum pembelajaran daring diharapkan dapat dimanfaatkan untuk mengembangkan model pembelajaran inovatif berbasis teknologi, dengan harapan efektif sebagai alternatif pembelajaran sistem tatap muka langsung di kelas (teacher-directed learning). Pada pembelajaran konvensional, selama ini mahasiswa cenderung hanya bersikap reaktif terhadap kondisi lingkungannya, tetapi tidak berperan aktif untuk lingkungannya (Yuniarti, 2010). Pembelajaran daring dapat meningkatkan interaktivitas dan efisiensi belajar karena memberikan mahasiswa potensi yang lebih tinggi untuk berkomunikasi lebih banyak dengan dosen, rekan, dan mengakses lebih banyak materi pembelajaran (Zhafira, Ertika \& Chairiyaton, 2020).

Pembelajaran daring pada awal pandemi covid-19 di Fakultas Sains, Teknik, dan Terapan (FSTT) Universitas Pendidikan Mandalika Semester Genap Tahun Akademik 2019/2020 diberlakukan secara mendadak karena jadwal perkuliahan dengan metode konvensional (tatap muka) sudah mulai berlangsung. Akibatnya, pembelajaran daring diselenggarakan dengan menggunakan media memungkinkan untuk digunakan oleh dosen dan mahasiswa. Oleh sebab itu, diperlukan adanya pemetaan persepsi mahasiswa tentang efektivitas pelaksanaan pembelajaran daring pada Pendidikan Olahraga Universitas Pendidikan Mandalika di Semester Genap Tahun Akademik 2019/2020.

\section{METODE PENELITIAN}

Studi ini merupakan penelitian ekploratif yang digunakan untuk mendeskripsikan persepsi mahasiswa pendidikan olahraga tentang pembelajaran daring (Muliadi, Mirawati \& Prayogi, 2021; Muliadi, 2020; Sugiyono, 2017; Arikunto, 2016; Singarimbun \& Sofyan, 2006). Responden penelitian ini adalah mahasiswa Pendidikan Olahraga Universitas Pendidikan Mandalika sebanyak 166 orang yang diperoleh dengan teknik convenience sampling karena mempertimbangkan aksesibilitas responden dalam mengisi angket secara online pada masa pandemi covid-19 (Fink, 2011). Intrumen yang digunakan adalah angket tertutup dengan pilihan jawaban yang berdegradasi berdasarkan skala likert (Muliadi, 2020; Muliadi \& Mirawati, 2020; Muliadi, Asri \& Lestarini, 2020). Angket persepsi mahasiswa terhadap pembelajaran online yang digunakan 
dalam penelitian ini disusun mengacu pada indikator persepsi meliputi interaksi pembelajaran, manajemen proses pembelajaran, evaluasi pembelajaran, dan lingkungan belajar (Adijaya \& Santosa, 2018). Indikator ini dikembangkan menjadi 15 pernyataan dan telah divalidasi oleh para pakar (expert) dan dinyatakan valid.

Data penelitian dianalisis menggunakan statistik deskriptif dan statistik inferensial. Statistik deskriptif digunakan untuk mendeskripsikan persepsi mahasiswa pendidikan olahraga terhadap pembelajaran daring pada masa pandemi covid-19. Rata-rata data persepsi dikonversi dalam bentuk kategori dengan mengacu pada kategori penilaian sikap sebagai berikut:

Tabel 1. Interpretasi skor persepsi mahasiswa

\begin{tabular}{cc}
\hline Rata-rata skor & Interpretasi \\
\hline $3,51-4,00$ & Sangat Baik \\
$2,51-3,50$ & Baik \\
$1,51-2,50$ & Cukup Baik \\
$1,00-1,50$ & Kurang Baik \\
\hline Statistik inferensial digunakan untuk
\end{tabular}

mengetahui perbedaan persepsi mahasiswa terhadap pembelajaran daring ditinjau berdasarkan gender. Teknik analisis yang digunakan adalah uji Kruskal Wallis pada taraf signifikansi $5 \%$, uji ini digunakan karena varians data tidak homogen dan tidak terdisribusi normal. Rumusan hipotesis statistik yaitu H0: $\mu 1=\mu 2$ (tidak ada perbedaan signifikan minat berwirausaha antara mahasiswa laki-laki dan perempuan) dan $\mathrm{H} 1: \mu 1 \neq \mu 2$ (ada perbedaan signifikan minat berwirausaha antara mahasiswa laki-laki dan perempuan). Jika hasil analisis signifikan atau $p$-value uji Kruskal Wallis lebih kecil dari 0,05, maka H0 ditolak dan $\mathrm{H} 1$ terima atau sebaliknya.

\section{HASIL DAN PEMBAHASAN}

Hasil respon mahasiswa diperoleh informasi bahwa media pembelajaran daring yang digunakan dosen pendidikan olahraga pada semester genap Tahun Akademik 2019/2020 yaitu WhatsApp, Google Classroom, dan Zoom Meeting. Analisis data tentang penggunaan media pembelajaran daring yang digunakan dosen diketahui bahwa
72,29\% mahasiswa menyebutkan WhatsApp, $22,90 \%$ mahasiswa menyebutkan Google Classroom, dan 4,81\% mahasiswa menyebutkan Zoom Meeting. Deskripsi data ini menggambarkan bahwa pembelajaran daring yang diselenggarkan dosen umumnya menggunakan WhatsApp.

Deskripsi data hasil pengukuran persepsi mahasiswa terhadap pembelajaran daring pendidikan biologi pada semester genap Tahun Akademik 2019/2020 di masa pandemi covid19 disajikan pada Tabel 2 berikut ini.

Tabel 2. Persepsi mahasiswa tentang pembelajaran daring

\begin{tabular}{lcccc}
\hline \multicolumn{1}{c}{ Gender } & n & $\begin{array}{c}\boldsymbol{\Sigma} \\
\text { Skor }\end{array}$ & $\begin{array}{c}\text { Rata- } \\
\text { Rata }\end{array}$ & Kategori \\
\hline Laki-laki & 141 & 314,14 & 2,23 & Cukup baik \\
Perempuan & 25 & 50,43 & 2,02 & Cukup baik \\
\hline
\end{tabular}

Deskripsi data hasil pengukuran pada tabel 1 menunjukkan bahwa rata-rata skor persepsi mahasiswa pendidikan olahraga terhadap pembelajaran daring ditinjau dari jenis kelamin yaitu laki-laki sebesar 2,23 dengan kategori Cukup Baik dan perempuan sebesar 2,02 dengan kategori Cukup Baik.

Data perbedaan persepsi mahasiswa terhadap pembelajaran daring berdasarkan gender dianalisis menggunakan statistik inferensial, dengan syarat varians data homogen dan terdistribusi normal. Hasil uji homogenitas (Levenestest) dan normalitas (Kolmogorov-Smirnov's test) dijadikan pada Tabel 3 berikut ini.

Tabel 3. Hasil uji homogenitas dan normalitas

\begin{tabular}{ccccc}
\hline \multirow{3}{*}{$N$} & \multicolumn{2}{c}{ Homogenitas } & \multicolumn{2}{c}{ Normalitas } \\
\cline { 2 - 5 } & $\begin{array}{c}\text { Levenes } \\
\text { Statistic } \\
\text { test score }\end{array}$ & Sig. & $\begin{array}{c}\text { Kolmogor } \\
\text { ov- } \\
\text { Smirnov's } \\
\text { test score }\end{array}$ & Sig. \\
\hline 49 & 0,334 & 0,564 & 1,148 & 0,143 \\
\hline
\end{tabular}

Hasil uji homogenitas (Levenes test) sebesar 0,334 dengan nilai signifikansi sebesar 0,564 lebih besar dari alpha pengujian $(>0,05)$, artinya varians data homogen dan hasil uji normalitas (Kolmogorov-Smirnov's test) sebesar 1,148 dengan nilai signifikansi sebesar 0,143 lebih kecil dari alpha pengujian $(>0,05)$, artinya data terdistribusi normal.

Data persepsi mahasiswa terhadap pembelajaran daring terdistribusi normal dan homogen, maka data perbedaan persepsi mahasiswa terhadap pembelajaran daring 
berdasarkan gender dianalisis menggunakan statistik parametrik yaitu uji-t. Hasil uji-t disajikan pada Tabel 4 berikut ini.

Tabel 4. Hasil uji t (independent sampel test)

\begin{tabular}{|c|c|c|c|c|c|c|}
\hline & \multirow[b]{2}{*}{ Group } & & \multicolumn{4}{|c|}{ t-test for Equality for Means } \\
\hline & & & $t$ & $d f$ & Sig. & $\begin{array}{c}\text { Mean } \\
\text { diff. }\end{array}$ \\
\hline $\begin{array}{c}\text { Persepsi } \\
\text { Mahasis } \\
\text { wa }\end{array}$ & $\begin{array}{c}\text { Equal } \\
\text { Varian } \\
\text { ces } \\
\text { Assum } \\
\text { ed }\end{array}$ & $\begin{array}{c}\text { Pendidikan } \\
\text { Olahraga }\end{array}$ & $\begin{array}{l}2,2 \\
99\end{array}$ & 164 & 0,023 & 2,95149 \\
\hline
\end{tabular}

Hasil uji-t menunjukkan bahwa nilai signifikansi sebesar 0,023 lebih kecil dari nilai alpha pengujian $0,05 \quad(<0,05)$, sehingga $\mathrm{H}_{1}$ diterima dan $\mathrm{H}_{0}$ ditolak yang artinya bahwa ada perbedaan yang signifikan persepsi mahasiswa terhadap pembelajaran daring antara mahasiswa berjenis kelamin laki-laki dan perempuan.

Elaborasi hasil penelitian ini menunjukkan bahwa persepsi mahasiswa terhadap pembelajaran daring pada pendidikan olahraga di Semester Genap Tahun Akademik 2019/2020 atau awal pandemi covid-19 adalah masih dalam kategori "Cukup Baik" atau belum mencapai kategori "Baik". Kondisi ini tentunya dipengaruhi oleh banyak faktor, salah satunya adalah faktor persiapan awal pembelajaran daring yang belum maksimal, mengingat pada penerapan pembelajaran daring pada semester genap Tahun Akademik 2019/2020 berlangsung pada awal merebahnya pandemi yang bersifat mendadak karena pada saat itu, proses pembelajran tatap muka (luring) sudah dimulai. Persiapan yang tidak maksimal tentu sangat mempengaruhi kesiapan semua pihak baik itu dosen, mahasiswa, maupun secara kelembagaan di Universitas Pendidikan Mandalika karena harus menyediakan fasilitas pendukung pembelajaran daring. Hal ini sesuai dengan pendapat Oktavian \& Aldya (2020); Ulfah \& Suryantoro (2020); Daheri, et al (2020) bahwa sesungguhnya pembelajaran daring membutuhkan effort dan dukungan yang maksimal dari semua pihak baik itu pendidik, peserta didik, lembaga pendidikan, dan keluarga. Semua pihak yang terkait diharapkan mampu menciptakan lingkungan belajar yang integratif dan memenuhi berbagai komponen esensial pembelajaran daring yakni diskursif, adaptif, interaktif dan reflektif.
Pelaksanaan pembelajaran daring yang sifatnya mendadak setelah pembelajaran tatap muka (konvensional) berlangsung, tentu 'memaksa' dosen menggunakan media pembelajaran daring yang dimiliki oleh semua mahasiswa dan dapat dioperasionalkan. Hasil penelitian ini menunjukkan bahwa media WhatsApp menjadi media yang dipilih oleh sebagian besar dosen, sebagaimana pengakuan $72,29 \%$ mahasiswa. WhatsApp adalah salah satu media sosial yang familiar dengan sistem synchronous atau asynchronous. Penggunaan media WhatsApp, membuat pembelajaran daring kurang efektif karena tidak dapat memafasilitasi Synchronous Learning dalam jumlah banyak ( $\leq 8$ orang), sehingga tidak memungkinkan adanyan interaksi dua arah antara dosen dengan mahasiswa ataupun antar mahasiswa. Pada akhirnya dosen cenderung hanya dapat memfasilitasi pembelajaran dalam bentuk Asynchronous Learning (ASL), dimana dosen memberikan pembelajaran dengan mengirimkan tulisan, rekaman suara, video, dan tugas mandiri. Oleh karena itu, mahasiswa akan mendapatkan penjelasan langsung yang terbatas dari dosen. Hal ini sebagaimana dijelaskan Batubara \& Batubara (2020) bahwa penjelasan detil dari pendidik melalui pesan grup apalagi video cukup jarang didapat. Padahal video penjelasan atau tutorial dapat memberikan pemahaman lebih baik dibandingkan hanya diberikan tuga mandiri. Hasil penelitian Daheri, et al (2020) bahwa $85 \%$ responden mengharapkan pendidik memberikan penjelasan yang memadai untuk tugas yang diberikan. Mahasiswa berasumsi bahwa materi dan tugas mandiri tidak cukup karena perlu penjelasan secara langsung oleh dosen (Sadikin \& Hakim, 2019).

Respon mahasiswa dalam penelitian menegaskan bahwa pembelajaran daring memiliki keterbatasan dalam proses interaksi, diskusi, kolaborasi, umpan balik. Kondisi ini membuat mahasiswa mengalami keterbatasan dalam menyampaikan pendapatan, pertanyaan, dan ketidakpahaman akan materi yang dihadapi dalam pembelajaran daring, sehingga memungkinkan untuk terjadi miskomunikasi antara dosen dan mahasiswa ataupun antar mahasiswa. Hal ini sesuai dengan pendapat 
Sadikin \& Hamidah (2020) bahwa pembelajaran daring memiliki tantangan khusus, lokasi mahasiswa dan dosen yang terpisah menyebabkan dosen tidak dapat berinteraksi, membimbing, dan mengawasi secara langsung setiap kegiatan mahasiswa selama proses pembelajaran. Akibatnya, tidak ada jaminan bahwa mahasiswa sunguhsungguh dalam mendengarkan elaborasi materi dari dosen, sehingga dimungkinkan adanya miskomunikasi. Mahasiswa lebih sering menghayal pada perkuliahan daring dibandingkan ketika kuliah tatap muka (Szpunar, Moulton, \& Schacter, 2013).

Keterbatasan pembelajaran daring yang menjadi temuan penelitian, memunculkan adanya sisi positifnya dalam membentuk kemandirian belajar mahasiswa. Mahasiswa mengakui bahwa selama proses pembelajaran daring, membuatnya lebih giat belajar dan madiri dalam menyelesaikan berbagai bentuk tugas perkuliahan. Hal ini sesuai dengan hasil penelitian Sadikin \& Hamidah (2020) bahwa pembelajaran daring juga memiliki kelebihan untuk menumbuhkan kemandirian belajar (self regulated learning) peserta didik. Penggunaan aplikasi online mampu meningkatkan kemandirian belajar (Oknisih \& Suyoto, 2019). Pembelajaran daring lebih bersifat berpusat pada peserta didik yang menyebabkan mereka mampu memunculkan tanggung jawab dan otonomi dalam belajar (learning autuonomy) (Kuo et al., 2014 dalam Sadikin \& Hamidah (2020). Lebih lanjut dipertegas oleh Aina (2016) bahwa belajar secara daring menuntut mahasiswa mempersiapkan sendiri pembelajarannya, mengevaluasi, mengatur dan secara simultan mempertahankan motiviasi dan mina dalam belajar (Sobron \& Bayu, 2019).

Hasil penelitian ini juga menjelaskan bahwa persepsi mahasiswa terhadap pembelajaran daring dipengaruhi oleh gender mahasiswa. Hal ini ditunjukkan dengan adanya perbedaan signifikan persepsepsi mahasiswa berjenis kelamin perempuan dan laki-laki. Hal ini sesuai dengan hasil studi Okwumabua et al (2010) bahwa terdapat populasi yang semakin beragam dan terlibat dalam pembelajaran online. Karakteristik penting lainnya yang memengaruhi persepsi siswa tentang pembelajaran online adalah gender. Gender merupakan variabel produktif yang dapat digunakan untuk mengetahui suatu informasi, sehingga persepsi mahasiswa pria dan wanita cenderung berbeda terhadap suatu informasi (Muliadi, 2020). Setyawan (2016) menjelaskan bahwa gender memiliki peranan dalam memoderasi pengaruh pengetahuan terhadap persepsi, sikap, dan prilaku mahasiswa. Selanjutnya Bae at al., (2014) menegaskan bahwa perbedaan dasar biologis antara mahasiswa laki-laki dan perempuan, memungkinkan mereka untuk mengembangkan persepsi, sikap dan prilaku yang berbeda.

\section{KESIMPULAN}

Hasil studi menunjukkan bahwa (1) Persepsi mahasiswa terhadap pembelajaran daring pada Pendidikan Olahraga ditinjau dari gender yaitu laki-laki memiliki rata-rata skor sebesar 2,23 dengan kategori Cukup Baik dan perempuan sebesar 2,02 dengan kategori Cukup Baik; (2) Ada perbedaan yang signifikan persepsi mahasiswa terhadap pembelajaran daring antara mahasiswa berjenis kelamin laki-laki dan perempuan yang dibuktikan dengan nilai signifikansi sebesar 0,023 lebih kecil dari nilai alpha pengujian $0,05(<0,05)$.

\section{DAFTAR PUSTAKA}

Arikunto. (2016). Prosedur Penelitian (Suatu Pendekatan Praktik). Jakarta: Rineka Cipta.

Bae, T.J., Qian, S., Miao, C., \& Fiet, J.O. (2014). The Relationship Between Entrepreneurship Education and Entrepreneurial Intentions. Sage Jurnals, 38 (2), 217-254.

Batubara, H. H., \& Batubara, D. S. (2020). Penggunaan Video Tutorial untuk Mendukung Pembelajaran Daring di Masa Pandemi Virus Corona. Muallimuna: Jurnal Madrasah Ibtidaiyah, 5(2), 74-84. http://dx.doi.org/10.31602/muallimuna.v $5 \mathrm{i} 2.2950$

Daheri, M., Juliana, Deriwanto \& Amda, A.D. 
(2020). Efektivitas WhatsApp sebagai Media Belajar Daring. Jurnal Basicedu, $4 \quad$ (4), 775-783. https://doi.org/10.31004/basicedu.v4i4.4 $\underline{45}$

Fink, A. (2011). How to sample in surveys. In how to sample in surveys (2nd edition). Thousand Oaks, CA: SAGE Publication. https://us.sagepub.com/en-us/nam/howto-sample-in-surveys/book225416

Firman, F., \& Rahayu, S. (2020). Pembelajaran Online di Tengah Pandemi Covid-19. Indonesian Journal of Educational Science (IJES), 2 (2), 81-89. https://doi.org/10.31605/ijes.v2i2.659

Gultom, C.R. \& Sitanggang, S.G.M. (2020). Persepsi Mahasiswa Unika terhadap Kuliah Online di Masa Pandemi Covid 19. Jurnal Pendidikan Bahasa Indonesia dan Sastra (PEDISTRA), 3 (1), 6-15. http://dx.doi.org/10.1234/pbis.v3i1.771

Hilmiatussadiah, K.G. (2020). Hasil Belajar Mahasiswa Pendidikan Ekonomi dengan Pembelajaran Daring pada Masa Pandemi Covid-19. Jurnal Pendidikan Ekonomi Indonesia, 1 (2), 66-69.

Kuntarto, E. (2017). Keefektifan Model Pembelajaran Daring dalam Perkuliahan Bahasa Indonesia di Perguruan Tinggi. Indonesian Language Education and Literature, 3(1), 99-110. http://dx.doi.org/10.24235/ileal.v3i1.182 $\underline{0}$

Maulah, S., Nurul, F. \& Ummah, N.R. (2020). Persepsi Mahasiswa Biologi terhadap Perkuliahan Daring sebagai Sarana Pembelajaran Selama Pandemi Covid19. ALVEOLI: Jurnal Pendidikan Biologi, 1 (2), 49-61.

Muliadi, A., Prayogi, S., Bahalwan, F., Nirmala, W. \& Verawati, N.N.S.P. (2021). Online Learning During the Covid-19 Pandemic: Preservice Teacher's Perception. Jurnal Penelitian Pendidikan IPA, 7 (3), 464-467. https://doi.org/10.29303/jppipa.v7i3.787

Muliadi, A., Mirawati, B. \& Prayogi, S. (2021). The Effect Entrepreneurship Education and Subjective Norm on Biology Students' Self-Efficacy in
Entrepreneurial. Prisma Sains: Jurnal Pengkajian Ilmu dan Pembelajaran MIPA IKIP Mataram, 9 (1), 127-135. https://doi.org/10.33394/j-ps.v9i1.3981

Firdaus, L., Hunaepi, Muliadi, A. \& Fitriani, H. (2020). Respon mahasiswa terhadap pembelajaran online pada masa pandemi covid-19. Empiricism Journal, 1 (2), 6065. https://doi.org/10.36312/ej.v1i2.336

Muliadi, A., Mirawati, B. \& Jannah, H. (2021). Efektivitas Pembelajaran Daring di Masa Pandemi Covid-19: Persepsi Mahasiswa Pendidikan Biologi. Jurnal Ilmu Sosial dan Pendidikan, 5 (2), 625633.

Muliadi, A. (2020). Sikap Entrepreneur Mahasiswa Pendidikan Biologi. Jurnal Ilmu Sosial dan Pendidikan, 4 (3), 286291.

http://dx.doi.org/10.36312/jisip.v4i3.120 8

Muliadi, A. (2020). Perbedaan Gender dalam Sikap Entrepreneur Mahasiswa Pendidikan Biologi. Jurnal Ilmiah Mandala Education, 6 (2), 329-334. http://dx.doi.org/10.36312/jime.v6i2.143 $\underline{9}$

Muliadi, A. (2020). Microbiology Learning Based On Bioentrepreneurship: Prospective Teacher's Perception. Jurnal Ilmu Sosial dan Pendidikan, 4 (4), 352357. http://dx.doi.org/10.36312/jisip.v4i4.152 $\underline{7}$

Muliadi, A. \& Mirawati, B. (2020). The Impact of Personal Attitude and Subjective Norm on Entrepreneurial Interest of Biological Education Students. E-Saintika: Jurnal Penelitian dan Pengkajian Ilmu Pendidikan, 4 (3). https://doi.org/10.36312/esaintika.v4i3.307

Muliadi, A., Asri, I.H. \& Lestarini, Y. (2020). Efek Pengetahuan dan Lingkungan Keluarga terhadap Sikap Entrepreneur Mahasiswa. Educatio: Jurnal Ilmu Kependidikan, $\quad 15 \quad$ (2). https://doi.org/10.29408/edc.v15i2.2836

Oknisih, N., \& Suyoto, S. (2019). Penggunaan APLEN (aplikasi online) sebagai Upaya 
Kemandirian Belajar Siswa. Seminar NasionalPendidikan Dasar, 1 (1), 477 483.

http://eproceedings.umpwr.ac.id/index.p hp/semnaspgsd/article/view/1056/905

Oktavian, R., \& Aldya, R. F. (2020). Efektivitas Pembelajaran Daring Terintegrasi di Era Pendidikan 4.0. Didaktis: Jurnal Pendidikan dan Ilmu Pengetahuan, 20(2), 129-135. http://dx.doi.org/10.30651/didaktis.v20i2 . .4763

Okwumabua, T., Walker, K. M., Hu, X., and Watson, X. (2010). An Exploration of African American Students' Attitudes Toward Online Learning. Urban Education. 45 (5).

Pangondian, R. A., Santosa, P. I., \& Nugroho, E. (2019). Faktor-Faktor Yang Mempengaruhi Kesuksesan Pembelajaran Daring Dalam Revolusi Industri 4.0. Seminar Nasional Teknologi Komputer \& Sains (SAINTEKS), 1 (1), 56-60. https://www.prosiding.seminarid.com/index.php/sainteks/article/view/1 $\underline{22}$

Sadikin, A. \& Hamidah, A. (2020). Pembelajaran Daring di Tengah Wabah Covid-19. BIODIK: Jurnal Ilmiah Pendidikan Biologi, 6 (2), 214-224. https://doi.org/10.22437/bio.v6i2.9759

Saifuddin, M.F. (2017). E-Learning dalam Persepsi Mahasiswa. Jurnal Varia Pendidikan, 29 (2), 102-109.

Setyawan, A. (2016). Apakah Gender Bermakna Pada Model Pembentukan Minat Berwirausaha? Jurnal Manajemen Teori dan Terapan, 9 (2), 120-127.

http://dx.doi.org/10.20473/jmtt.v9i2.301 

Singarimbun, M. \& Efendi, S. (2006). Metode Penelitian Survai (Edisi Revisi). Jakarta Barat: Pustaka LP3ES Indonesia.

Sobron, A. N., \& Bayu, R. (2019). Persepsi Siswa dalam Studi Pengaruh Daring Learning Terhadap Minat Belajar IPA. SCAFFOLDING: Jurnal Pendidikan Islam dan Multikulturalisme, 1 (2), 3038. https://doi.org/10.37680/scaffolding.v1i2 .117

Sugiyono. (2017). Metode Penelitian Kualitatif, Kuantitatif, dan $R \& D$. Bandung: Alfabeta.

Szpunar, K. K., Moulton, S. T., \& Schacter, D. L. (2013). Mind wandering and education: From the classroom to online learning. Frontiers in Psychology, 4 (Article 495) 1-7. https://dx.doi.org/10.3389\%2Ffpsyg.201 $\underline{3.00495}$

Ulfah, Y., \& Suryantoro, A. (2020). Studi Awal Tentang Penggunaan Media Daring Selama Pandemi Corona Di SMPN Purworejo Lampung Tengah. $A l$ Jahiz: Journal of Biology Education Research, 1 (1), 34-43. https://ejournal.metrouniv.ac.id/index.php/AlJahiz/article/view/2046

Yuniarti, R.D. (2010). Potensi E-Learning melalui Sistem Kuliah On-Line dalam Meningkatkan Kualitas Pembelajaran di Prodi Tata Niaga Jurusan Pendidikan Ekonomi FPEB-UPI. Jurnal ANAJERIAL, 8 (16), 66-77. https://doi.org/10.17509/manajerial.v9i1. $\underline{1215}$

Zhafira, N.H., Ertika, Y. \& Chairiyaton. (2020). Persepsi Mahasiswa terhadap Perkuliahan Daring sebagai Sarana Pembelajaran Selama Masa Karantina Covid-19. Jurnal Bisnis dan Kajian Strategi Manajemen, 4 (1), 37-45. https://doi.org/10.35308/jbkan.v4i1.1981 